\title{
The Importance of Selecting Appropriate Rotation and Tank-Mix Partners for Novel SDHls to Enhance Botrytis Fruit Rot Control in Strawberry
}

\author{
Achour Amiri, ${ }^{1, \dagger}$ Adrian I. Zuniga, ${ }^{2}$ Leandro G. Cordova, ${ }^{2}$ and Natalia A. Peres ${ }^{2}$ \\ ${ }^{1}$ Department of Plant Pathology, Tree Fruit Research and Extension Center, Washington State University, Wenatchee, WA \\ 98801; and ${ }^{2}$ Gulf Coast Research and Education Center, University of Florida, Wimauma, FL 33598
}

\begin{abstract}
Botrytis fruit rot (BFR), caused by the necrotrophic fungus Botrytis cinerea, is the most important disease of strawberry and is mainly controlled by applications of fungicides from multiple chemical groups. To develop more effective and sustainable BFR management programs, field trials were conducted to evaluate the efficacy of fluopyram and penthiopyrad, two newly registered succinate dehydrogenase inhibitors (SDHIs), rotated or tank mixed with the multisites thiram and captan or the singlesites fludioxonil and fenhexamid. The treatments were applied at two different strawberry fields during the 2013-14 and 2014-15 seasons. Overall, tank mixtures of fluopyram and penthiopyrad increased yield and reduced BFR better than rotations with the same fungicides. The multisite thiram tank mixed with fluopyram reduced BFR incidence by 63 to $86 \%$ versus 56 to $84 \%$ when the two fungicides were rotated. Thiram tank mixed with penthiopyrad reduced BFR incidence by 55 to $72 \%$ versus 42 to $66 \%$ when rotated. Captan rotated or tank mixed with

fluopyram had a positive effect on yield and BFR incidence, whereas the combination of captan with penthiopyrad had negative impacts. Similarly, the single-site fenhexamid had significant positive impacts when rotated or tank mixed with fluopyram but resulted in poor BFR control when combined with penthiopyrad. The rotation of fludioxonil with both SDHIs had a significant positive effect, although its combination with fluopyram was more effective. The multirotation consisting of both SDHIs and different multi- and single-site fungicides did not provide a greater efficacy than the dual rotation or tank-mixture programs. Our findings suggest more scrutiny is needed when recommending tankmixture or rotation partners for new fungicides to ensure compatibility and enhanced BFR management. Future recommendations should emphasize the importance of such selections at an early stage for delaying fungicide resistance development and extending the lifespan of at-risk fungicides.
\end{abstract}

The polycyclic fungus Botrytis cinerea is a major threat to strawberry production in the Southeastern United States and worldwide. The pathogen infects leaves and can be very destructive to green and mature fruit, on which it causes gray mold or Botrytis fruit rot (BFR). In the absence of cultivars with actual resistance to $B$. cinerea, chemical control remains the main management strategy. In Florida, standard spray programs recommended for BFR management included an average of 20 weekly applications of multisite and single-site fungicides. More recently, strategies designed to time and reduce fungicide applications have been developed and implemented (Cordova et al. 2017; MacKenzie and Peres 2012). Besides the two multisites captan and thiram, 14 other single-site fungicides from six different chemical groups are registered to control BFR in Florida and the Southeastern United States (Whitaker et al. 2017).

The efficacy of current or future strategies implemented to manage BFR can be jeopardized by the widespread occurrence of fungicide resistance in the Botrytis populations. Several extensive surveys (Amiri et al. 2013, 2014; Fernández-Ortuño et al. 2014) conducted in strawberry fields across the eastern United States showed risks for potential control failure owing to limited fungicide efficacy (Amiri et al. 2012). Thus, not only was resistance widespread across the region, but resistance frequencies higher than $60 \%$ were common for numerous fungicides (Amiri et al. 2013, 2014; Fernández-Ortuño et al. 2014). More specifically, resistance frequencies as high as 90 , 85,75 , and $60 \%$ were observed to the methyl-benzamide carbamates, quinone outside inhibitors, the succinate dehydrogenase inhibitors (SDHIs), and anilinopyrimidines, respectively (Amiri et al. 2013; Fernández-Ortuño et al. 2014). Moderate resistance frequencies

${ }^{\dagger}$ Corresponding author: A. Amiri; E-mail: a.amiri@wsu.edu

Funding: This research was supported by a United States Department of Agriculture NIFA fund under project number 2014-51181-2237.

Accepted for publication 27 September 2018.

Modified: 16 Aug 2019.

() 2019 The American Phytopathological Society ranging between 20 and $40 \%$ were observed for the hydroxyanilide (Hyd) fenhexamid (Amiri et al. 2013; Amiri and Peres 2014; FernándezOrtuño et al. 2014). The phenylpyrrole (PP) fludioxonil was the only fungicide for which resistance was not detected in Florida (Amiri et al. 2013) but was sporadically found in some other southeastern states (Fernández-Ortuño et al. 2014). The SDHIs penthiopyrad, fluxapyroxad, and fluopyram were registered for management of BFR and other diseases in 2012 and 2015. Because of cross-resistance with boscalid, which has been used for over a decade, about $15 \%$ of isolates collected in Florida were resistant to penthiopyrad and fluxapyroxad, whereas $2 \%$ of the isolates were resistant to fluopyram, even before these new SDHIs were applied in commercial fields (Amiri et al. 2014). Similar scenarios have considerably limited the number of effective fungicides available and warrant the development of newer control strategies to extend the life of new and current effective fungicides.

Besides some sanitation practices (Mertely et al. 2000), aimed to reduce inoculum loads, rotations and tank mixtures of fungicides from different chemical groups have been recommended to extend the life of fungicides and improve management (Staub 1991). It is admitted that mixing fungicides will result in increased efficacy if additive or synergistic effects exist between the mixed active ingredients. Moreover, mixtures are expected to reduce the size of the population exposed to selection, which in a long term is anticipated to extend the efficacy of the mixed fungicides. However, there is a risk of selecting for double-resistant or multiresistant isolates if the pathogen is fit to adapt easily to multiple exogenous stresses (i.e., fungicides). Such risk is greater with "high risk" pathogens like $B$. cinerea in which isolates resistant to fungicides from six different chemical classes have been reported (Amiri et al. 2013; FernándezOrtuño et al. 2014; Oliveira et al. 2017). On the other hand, rotation of fungicides with different modes of action is thought to reduce selection time and may disturb the biochemical pathways of the fungus in a way to render it unfit to persist under field conditions.

The new generation of SDHIs (i.e., fluopyram, fluxapyroxad, and penthiopyrad) have been registered recently on strawberry and other crops to manage BFR and several other diseases. Although penthiopyrad is registered as a solo product (Fontelis), fluxapyroxad and 
fluopyram are premixed with existing fungicides such as pyraclostrobin and pyrimethanil. Knowing the high resistance frequency of $B$. cinerea from strawberry fields to pyraclostrobin $(>80 \%)$ and pyrimethanil $(>60 \%)$, the use of such mixtures may be a risky approach because fitness and resistance to some fungicides may increase the adaptation abilities of the pathogen to develop resistance to other fungicides regardless of their mode of action (Köller and Wilcox 2001; Luo and Schnabel 2008; Schoustra et al. 2005). Given that fludioxonil is the only fungicide expected to provide higher efficacy and that it will be used frequently in the years to come, it is important to develop long-term management strategies to extend the life of current or new fungicides with low resistance frequencies. Therefore, this study was designed to compare 19 fungicide combinations of multiand single-site fungicides and evaluate for their impact on yield and BFR development in strawberry fields.

\section{Materials and Methods}

Field plot description and experimental design. Field trials were conducted during the 2013-14 and 2014-15 seasons at a commercial strawberry field (N $27^{\circ} 59^{\prime} 45.9^{\prime \prime}$, W 82 $\left.2^{\circ} 3^{\prime} 51.2^{\prime \prime}\right)$ in Plant City, Florida, and at an experimental field (N $27^{\circ} 45^{\prime} 40.4^{\prime \prime}$, W 82 $\left.13^{\prime} 41.0^{\prime \prime}\right)$ at the Gulf Coast Research and Education Center in Wimauma, Florida. Both fields are located in the main strawberry production area of Hillsborough County, Florida. The two fields have been regularly sprayed for several years with fungicides commonly used to control
BFR and other strawberry diseases in Florida (Whitaker et al. 2017). The strawberry cultivars 'Florida Radiance', the most predominant cultivar in Florida developed in 2009 (Chandler et al. 2009), and Winterstar, developed in 2012 (Whitaker et al. 2012), were used at the commercial and experimental fields, respectively. The two cultivars have a similar susceptibility to $B$. cinerea. Bare-root transplants originating from Canadian nurseries were planted in late September to early October of each year in raised beds covered with black plastic mulch. The beds were about $90 \mathrm{~m}$ long, $71 \mathrm{~cm}$ wide, 15 to $18 \mathrm{~cm}$ high, and $40 \mathrm{~cm}$ distant from each other. Each bed consisted of two staggered rows of transplants $30-\mathrm{cm}$ apart divided into plots containing 18 plants each with a $90-\mathrm{cm}$ buffer zone between plots. The plots were arranged in a randomized complete block design with four replicate adjacent beds. The transplants were overhead-irrigated for 10 days to support establishment. Common commercial practices for annual strawberry (i.e., soil fumigation, fertilization, irrigation, and sprayings of pesticides other than fungicides) (Whitaker et al. 2017) were followed and maintained in the two trial fields.

Fungicides. Six fungicides were used in this study, including two multisites (captan and thiram) and four single-sites: fenhexamid (Hyd), fludioxonil (PP) + cyprodinil, fluopyram (SDHI), and penthiopyrad (SDHI) (Table 1). The two multisites thiram and captan are part of the overall spray recommendation program for managing diseases in strawberry (Legard et al. 2005; Whitaker et al. 2017). These two

Table 1. Description of fungicides and rates used in this study ${ }^{\mathrm{z}}$

\begin{tabular}{lllcll}
\hline Trade name & \multicolumn{1}{c}{ Active ingredient (\%) } & \multicolumn{1}{c}{ Chemical group } & FRAC group & Rate/ha & Source \\
\hline Captan 50W & Captan (48.9) & Phthalimides & M4 & $5.2 \mathrm{~kg}$ & Drexel Chemical, Memphis, TE \\
Thiram Granuflo & Thiram (75) & Dithio-carbamates & M3 & $5.9 \mathrm{~kg}$ & Taminco, Allentown, PA \\
Elevate & Fenhexamid (50) & Hydroxyanilide & 17 & $2.0 \mathrm{~kg}$ & Arysta Life Science, Cary, NC \\
Fontelis & Penthiopyrad (20.4) & Pyrazole-4-carboxamide & 7 & 0.6 liter & DuPont Crop Prot., Wilmington, DE \\
Luna Privilege & Fluopyram (41.2) & Pyridinyl-ethyl-benzamides & 7 & 0.63 liter & Bayer Crop Prot., Research \\
& & & & & Triangle Park, NC \\
Switch 62.5WG & Fludioxonil (25)+ cyprodinil (37.5) & Phenylpyrrole & $12+9$ & $1.2 \mathrm{~kg}$ & Syngenta Crop Prot., Greensboro, NC \\
\hline
\end{tabular}

${ }^{\mathrm{z}}$ FRAC $=$ Fungicide Resistance Action Committee.

Table 2. Rotational and tank-mixture treatments evaluated and their sequence of applications in two strawberry fields during the 2013-14 and 2014-15 seasons ${ }^{z}$

\begin{tabular}{|c|c|c|c|c|c|c|c|}
\hline \multirow{2}{*}{\multicolumn{3}{|c|}{ Treatment }} & \multirow[b]{3}{*}{ Partner } & \multicolumn{4}{|c|}{ Treatment tested } \\
\hline & & & & \multicolumn{2}{|c|}{$\begin{array}{l}\text { Commercial field } \\
\text { (Plant City) }\end{array}$} & \multicolumn{2}{|c|}{$\begin{array}{c}\text { Experimental } \\
\text { field (Wimauma) }\end{array}$} \\
\hline No. & SDHI & Strategy & & 2013-14 & 2014-15 & 2013-14 & 2014-15 \\
\hline 1 & & Single & Control & $X$ & $\mathrm{X}$ & $\mathrm{X}$ & $\mathrm{X}$ \\
\hline 2 & & & Capt & $X$ & $X$ & $\mathrm{X}$ & $\mathrm{X}$ \\
\hline 3 & & & Thir & $X$ & $X$ & $\ldots$ & $\mathrm{X}$ \\
\hline 4 & & & Flup & $\mathrm{X}$ & $X$ & $\mathrm{X}$ & $\mathrm{X}$ \\
\hline 5 & & & Penth & $\mathrm{X}$ & $X$ & $X$ & $\mathrm{X}$ \\
\hline 6 & Flup & Rotated & Capt & $\mathrm{X}$ & $\mathrm{X}$ & $\mathrm{X}$ & $\mathrm{X}$ \\
\hline 7 & & & Thir & $\mathrm{X}$ & $X$ & $\mathrm{X}$ & $\mathrm{X}$ \\
\hline 8 & & & Fenh & $\mathrm{X}$ & $\mathrm{X}$ & $\ldots$ & $\mathrm{X}$ \\
\hline 9 & & & Flud & $\mathrm{X}$ & $\mathrm{X}$ & $\ldots$ & $\mathrm{X}$ \\
\hline 10 & & Tank mixed & Capt & $\mathrm{X}$ & $\mathrm{X}$ & $\mathrm{X}$ & $\mathrm{X}$ \\
\hline 11 & & & Thir & $\mathrm{X}$ & $\mathrm{X}$ & $\mathrm{X}$ & $\mathrm{X}$ \\
\hline 12 & & & Fenh & $\mathrm{X}$ & $X$ & $\mathrm{X}$ & $\mathrm{X}$ \\
\hline 13 & Penth & Rotated & Capt & $\mathrm{X}$ & $X$ & $\mathrm{X}$ & $\mathrm{X}$ \\
\hline 14 & & & Thir & $\mathrm{X}$ & $\mathrm{X}$ & $\mathrm{X}$ & $\mathrm{X}$ \\
\hline 15 & & & Fenh & $\mathrm{X}$ & $\mathrm{X}$ & $\mathrm{X}$ & $\mathrm{X}$ \\
\hline 16 & & & Flud & $\mathrm{X}$ & $X$ & $\ldots$ & $\mathrm{X}$ \\
\hline 17 & & Tank mixed & Capt & $\mathrm{X}$ & $\mathrm{X}$ & $\ldots$. & $\mathrm{X}$ \\
\hline 18 & & & Thir & $\mathrm{X}$ & $\mathrm{X}$ & $\ldots$ & $\mathrm{X}$ \\
\hline 19 & & & Fenh & $\mathrm{X}$ & $\mathrm{X}$ & $\ldots$ & $\mathrm{X}$ \\
\hline 20 & Multi-rotation & Rotated & Multiple & $\mathrm{X}$ & $\mathrm{X}$ & $\ldots$ & $\mathrm{X}$ \\
\hline
\end{tabular}

\footnotetext{
${ }^{\mathrm{z}}$ Treatments were started on December 28 and December 23 in the 2013-14 and 2014-15 seasons, respectively, and were applied sequentially as described in the table above. Dash (-) indicates no treatment was applied. X and ellipsis (...) indicate treatment tested and not tested, respectively. SDHI $=$ succinate dehydrogenase inhibitor; Capt $=$ captan; Thir $=$ thiram; Flup $=$ fluopyram; Penth $=$ penthiopyrad; Fenh $=$ fenhexamid; and Flud $=$ fludioxonil.
} 
fungicides were included to evaluate the effect of combined single- and multisite fungicide treatments on BFR development. Fludioxonil was included because no resistance has been reported in Florida, and it is considered as "low risk" for fungicide resistance development. Fenhexamid was included because of the relatively low resistance frequency compared with the other fungicides (Amiri et al. 2013; Amiri and Peres 2014), and it is classified as "moderate" for resistance development. Penthiopyrad and fluopyram are two new-generation SDHIs registered in Florida in 2013 and 2015, respectively. Both SDHIs were found to be highly active in controlling BFR, but some cross-resistance with boscalid was detected (Amiri et al. 2014), and their usage is expected to increase in the future.

Treatment applications. Fungicides were tested solo (multisites) or within a sequence of rotational and tank-mixing programs. Weekly sprays were initiated late December and continued until the end of the season in February (Table 2). In addition to a nontreated control, the multisites captan and thiram were applied separately on a weekly basis for up to eight applications in a season. The SDHIs fluopyram and penthiopyrad were applied alone for up to four applications per season to reflect label restrictions. Solo applications of fludioxonil and fenhexamid were not included in this study because they have been previously tested and because the main goal of this study was to find the most suitable partners to rotate or tank mix with the SDHIs. Dual rotational programs included fluopyram and penthiopyrad, each rotated with captan, thiram, fludioxonil, or fenhexamid for up to four applications in a season. A multirotation treatment included the same six fungicides but applied no more than two applications in each season (Table 2). Applications were made in a way to avoid successive sprays of the same fungicide or fungicides from the same chemical group. For the tank-mixture programs, fluopyram and penthiopyrad were tank mixed with thiram, captan, or fenhexamid. These treatments were tested to evaluate the effect of tank mixing multisites with the SDHIs and that of a single-site with a "medium risk" (fenhexamid) for fungicide resistance development with "high risk" fungicides such as the SDHIs. Fludioxonil was not included in the tank-mixing programs because it is unlikely growers would apply such a combination in their fields owing to the excessive cost. All fungicides were applied at the recommended label rate shown in Table 1. Sprays at both fields were applied using a $\mathrm{CO}_{2}$ backpack sprayer with a boom mounted with hollow cone nozzles calibrated to deliver the equivalent of 935 liters/ha at $412 \mathrm{kPA}$. All plots at both fields received regular insecticide and herbicide sprays.

Data collection and analyses. Weather data, including temperature and leaf wetness duration, were obtained from the Strawberry Advisory System (http://agroclimate.org/tools/sas/tools/) (Pavan et al. 2011). Mature berries were harvested twice a week starting 1 week after the first fungicide application until 2 weeks after the last application. At each harvest, fruit from each plot were weighed and sorted into culls and marketable fruit, which were used to determine yield expressed in $\mathrm{g} /$ plot. Nonmarketable, including diseased fruit, were used to determine BFR incidence, which was used to calculate a $\%$ reduction relative to the control. Yield and BFR incidence data from all harvests were summed at the end of each season. Data were arcsine-transformed and subjected to one-way ANOVA and Fisher's least significant difference test at $P \leq 0.05$ for each season and field location, separately. Synergistic, additive, or antagonistic effects of captan and thiram with either fluopyram or penthiopyrad were calculated using the formula $E=X+$ $[Y(100-X)] / 100$ (Gowing 1960), where $X$ is the actual control value in plots treated with one partner of the rotation or tank mixture and $Y$ is the actual control value in plots treated with the other partner of the rotation or tank mixture. $E$ values significantly and not significantly lower than the actual \% control indicate synergistic and additive interactions, respectively, whereas an $E$ value significantly higher than the actual control value indicates antagonism (Couch and Smith 1991). Statistical analyses were performed using JMP statistical software (SAS Institute, Cary, NC).

\section{Results}

Effect of rotation and tank-mix treatments on yield. With the exception of the experimental field in Wimauma during the 2013-14 season $(P=0.858)$, there was an overall significant treatment effect on strawberry yield (Table 3, Fig. 1). Thiram applied as a solo product increased yield significantly compared with a solo captan application at the commercial field in Plant City in 2014 and 2015 (Fig. 1A and B) and at the experimental field in 2015 (Fig. 1D). Applications of fluopyram alone increased yield significantly compared with the nontreated control and solo penthiopyrad applications in both years at the commercial field in Plant City (Fig. 1A and B) and in 2014 at the experimental field in Wimauma (Fig. 1C). Tank mixing fluopyram with captan, thiram,

Table 2. (Continued from previous page)

\begin{tabular}{|c|c|c|c|c|c|c|c|c|c|}
\hline \multicolumn{10}{|c|}{ Application order (week) } \\
\hline 1 & 2 & 3 & 4 & 5 & 6 & 7 & 8 & 9 & 10 \\
\hline - & - & - & - & - & - & - & - & - & - \\
\hline Thir & Thir & - & Thir & Thir & - & Thir & Thir & Thir & Thir \\
\hline Capt & Capt & - & Capt & Capt & - & Capt & Capt & Capt & Capt \\
\hline Flup & - & - & Flup & - & - & Flup & - & - & Flup \\
\hline Penth & - & - & Penth & - & - & Penth & - & - & Penth \\
\hline Flup & Capt & - & Flup & Capt & - & Flup & Capt & - & Flup \\
\hline Flup & Thir & - & Flup & Thir & - & Flup & Thir & - & Flup \\
\hline Flup & Fenh & - & Flup & Fenh & - & Flup & - & Fenh & Capt \\
\hline Flup & Flud & - & Flup & Flud & - & Flup & - & Flud & Capt \\
\hline Flup+Capt & Capt & - & Flup+Capt & Capt & - & Flup+Capt & Capt & - & Flup+Capt \\
\hline Flup+Thir & Thir & - & Flup+Thir & Thir & - & Flup+Thir & Thir & - & Flup+Thir \\
\hline Flup+Fenh & Capt & - & Flup+Fenh & Capt & - & Flup+Fenh & Capt & - & Flup+Fenh \\
\hline Penth & Capt & - & Penth & Capt & - & Penth & Capt & - & Penth \\
\hline Penth & Thir & - & Penth & Thir & - & Penth & Thir & - & Penth \\
\hline Penth & Fenh & - & Penth & Fenh & - & Penth & - & Fenh & Capt \\
\hline Penth & Flud & - & Penth & Flud & - & Penth & - & Flud & Capt \\
\hline Penth+Capt & Capt & - & Penth+Capt & Capt & - & Penth+Capt & Capt & - & Penth+Capt \\
\hline Penth+Thir & Thir & - & Penth+Thir & Thir & - & Penth+Thir & Thir & - & Penth+Thir \\
\hline Penth+Fenh & Capt & - & Penth+Fenh & Capt & - & Penth+Fenh & Capt & & Penth+Fenh \\
\hline Flup & Capt & - & Penth & Thir & - & Flud & Fenh & Capt & Flup \\
\hline
\end{tabular}


or fenhexamid increased yield significantly compared with a rotation with the same fungicides in $66.6 \%$ of cases (six of nine treatments across two seasons) at both fields (Fig. 1A, B, and D). Tank mixing penthiopyrad with captan, thiram, or fenhexamid increased yield significantly in $55 \%$ of cases compared with its rotation with the same partners. All treatments rotated or tank mixed with fluopyram increased yield compared with the control, whereas a rotation of penthiopyrad with either captan or fenhexamid reduced yield at both fields in 2014 (Fig. 1A and C). The dual fluopyram-fludioxonil rotation provided additional yield gain of 1,400 and 3,950 g/plot at the experimental field (Wimauma) and commercial field (Plant City), respectively, in 2014. In the following season, the yield gain was 2,850 and 3,000 g/plot in the experimental and commercial field, respectively. Although the multirotation of six different fungicides increased yield in both years and locations by 1,440 to $3,907 \mathrm{~g} /$ plot compared with the dual rotations or tank mixtures, a significant effect was only observed in 2014 at the experimental field (Fig. 1C).

Rotation and tank mixing of fluopyram or penthiopyrad increased yield compared with the solo applications of the two SDHIs (Fig. 2). Thus, tank mixtures increased yield in $75 \%$ of the combinations tested, whereas $63 \%$ of the rotation combinations tested increased yield (Fig. 2). Rotation and tank mixtures increased yield more under higher disease pressure conditions, as observed in the Plant City

Table 3. Analysis of variance describing effects of treatments on cumulative Botrytis fruit rot (BFR) incidence and marketable yield at two locations during the 2013-14 and 2014-15 seasons

\begin{tabular}{|c|c|c|c|c|c|c|c|}
\hline \multirow[b]{2}{*}{ Season } & \multirow[b]{2}{*}{ Source } & \multicolumn{3}{|c|}{ Commercial field (Plant City) } & \multicolumn{3}{|c|}{ Experimental field (Wimauma) } \\
\hline & & df & Mean square & $P>F$ & df & Mean square & $P>F$ \\
\hline \multirow[t]{4}{*}{ 2013-14 } & $\begin{array}{l}\text { Yield } \\
\text { Treatment }\end{array}$ & 17 & $2,720,322$ & $<0.0001$ & 17 & $1,839,749$ & 0.858 \\
\hline & Error & 54 & 433,931 & $\ldots$ & 54 & $2,949,285$ & \\
\hline & $\begin{array}{c}\text { BFR incidence } \\
\text { Treatment }\end{array}$ & 17 & 0.0211 & $<0.0001$ & 17 & 0.0072 & 0.0008 \\
\hline & Error & 54 & 0.0046 & . & 54 & 0.0023 & \\
\hline \multirow[t]{4}{*}{ 2014-15 } & $\begin{array}{l}\text { Yield } \\
\text { Treatment }\end{array}$ & 17 & $4,802,926$ & $<0.0001$ & 17 & $3,051,047$ & 0.0238 \\
\hline & Error & 54 & $1,218,258$ & $\ldots$ & 54 & $1,355,873$ & $\ldots$ \\
\hline & $\begin{array}{l}\text { BFR incidence } \\
\text { Treatment }\end{array}$ & 17 & 0.0370 & $<0.0001$ & 17 & 0.0036 & 0.0118 \\
\hline & Error & 54 & 0.0049 & $\ldots$ & 54 & 0.0014 & $\ldots$ \\
\hline
\end{tabular}
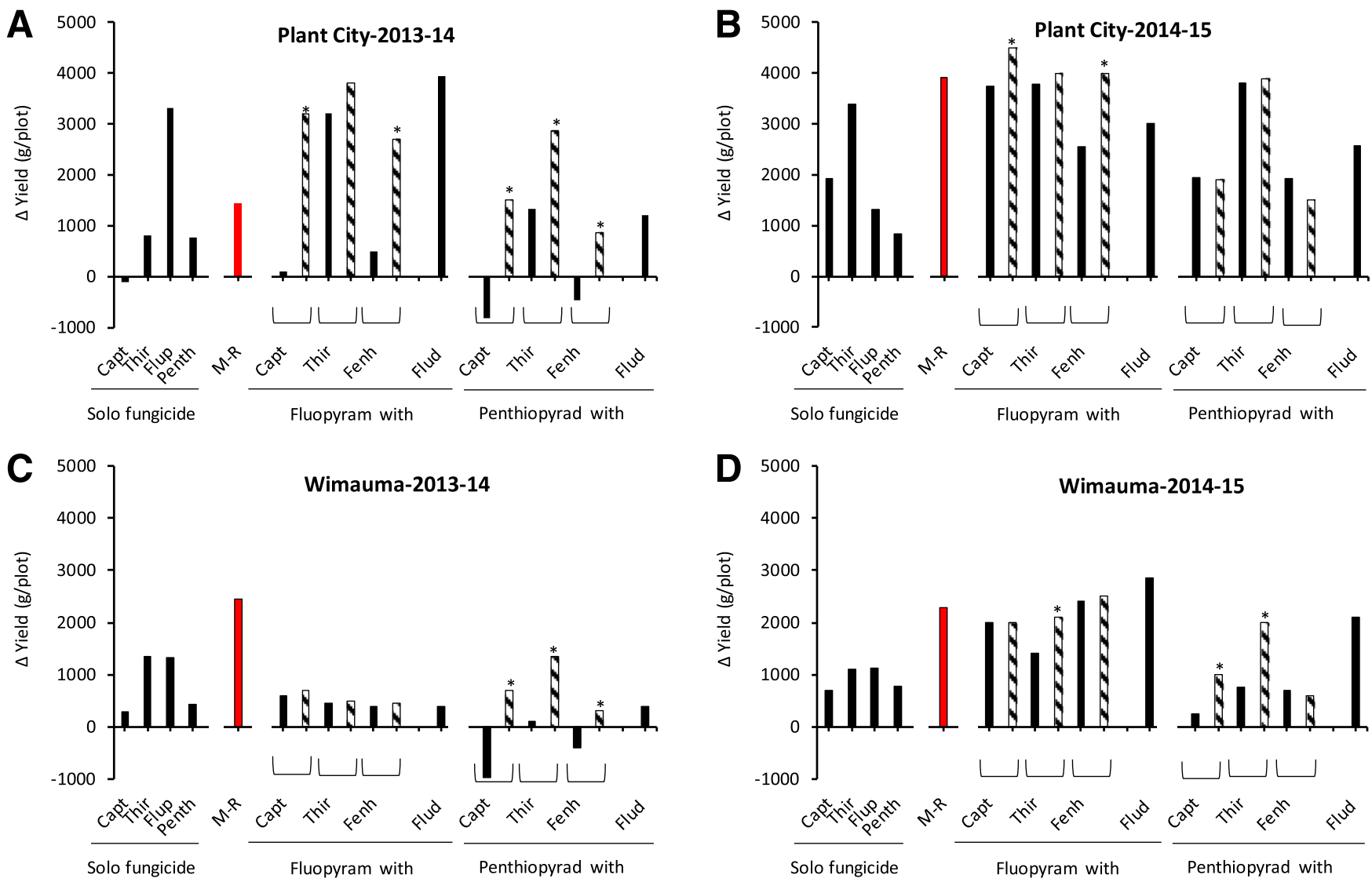

Fig. 1. Effect of spray programs on gain in yield at a commercial field in Plant City (A and B) and at the experimental field in Wimauma (C and D) during the 2013-14 and 2014-15 seasons. Filled and dashed bars show data from the rotation and tank-mixing programs, respectively. Data are expressed as $\Delta y$ ield $=$ yield treatment - yield nontreated control, and data are the mean yield values from four replicate plots. Bars within the same fungicide (fluopyram or penthiopyrad) with an asterisk are significantly different following an ANOVA and mean separation using Fisher's LSD test at $P \leq 0.05$. Capt, Thir, Flup, Penth, Flud, and Fenh indicate captan, thiram, fluopyram, penthiopyrad, fludioxonil, and fenhexamid, respectively. M-R refers to multiple rotation of fungicides. 
fields and also during the 2014-15 season (Fig. 2A and C). In the field located in Wimauma, where Botrytis pressure is usually lower, the rotation and tank-mixture treatments had an average positive effect on yield in the 2014-15 season, but a negative effect was observed in the 2013-14 season (Fig. 2B and D) when the overall BFR incidence was below $10 \%$.

Effect of rotation and tank-mix treatments on BFR incidence. The overall treatment effect on BFR incidence was significant for both fields and years $(P<0.0001$, Table 3$)$. The weather conditions were more conducive to BFR in 2015 than in 2014 (data not shown). Thus, BFR incidence in the nontreated plots was 9.7 and $16.9 \%$ at the experimental (Wimauma) and commercial (Plant City) fields in 2014 versus 16.5 and $30.1 \%$, respectively, in 2015 . Eight solo thiram applications in a season reduced BFR incidence by about $50 \%$ compared with the control in both years and fields, versus a 14 to $35 \%$ reduction for solo captan applications (Table 4). Four solo fluopyram applications per season reduced BFR incidence 51 to $84 \%$ versus 32 to $58 \%$ for penthiopyrad solo applications across locations and years. In 2014 at the experimental field in Wimauma, the fluopyramfludioxonil rotation reduced BFR the greatest $(74 \%)$ followed by the penthiopyrad-fludioxonil rotation $(68 \%)$, and other treatments by 60 to $67 \%$. Under lower disease pressure conditions in 2014 at the commercial field in Plant City, all fluopyram-based treatments reduced BFR incidence by more than $83 \%$ regardless of being rotated or tank mixed with this SDHI (Table 4). On the other hand, only a penthiopyrad-fludioxonil rotation and a penthiopyrad-thiram tank

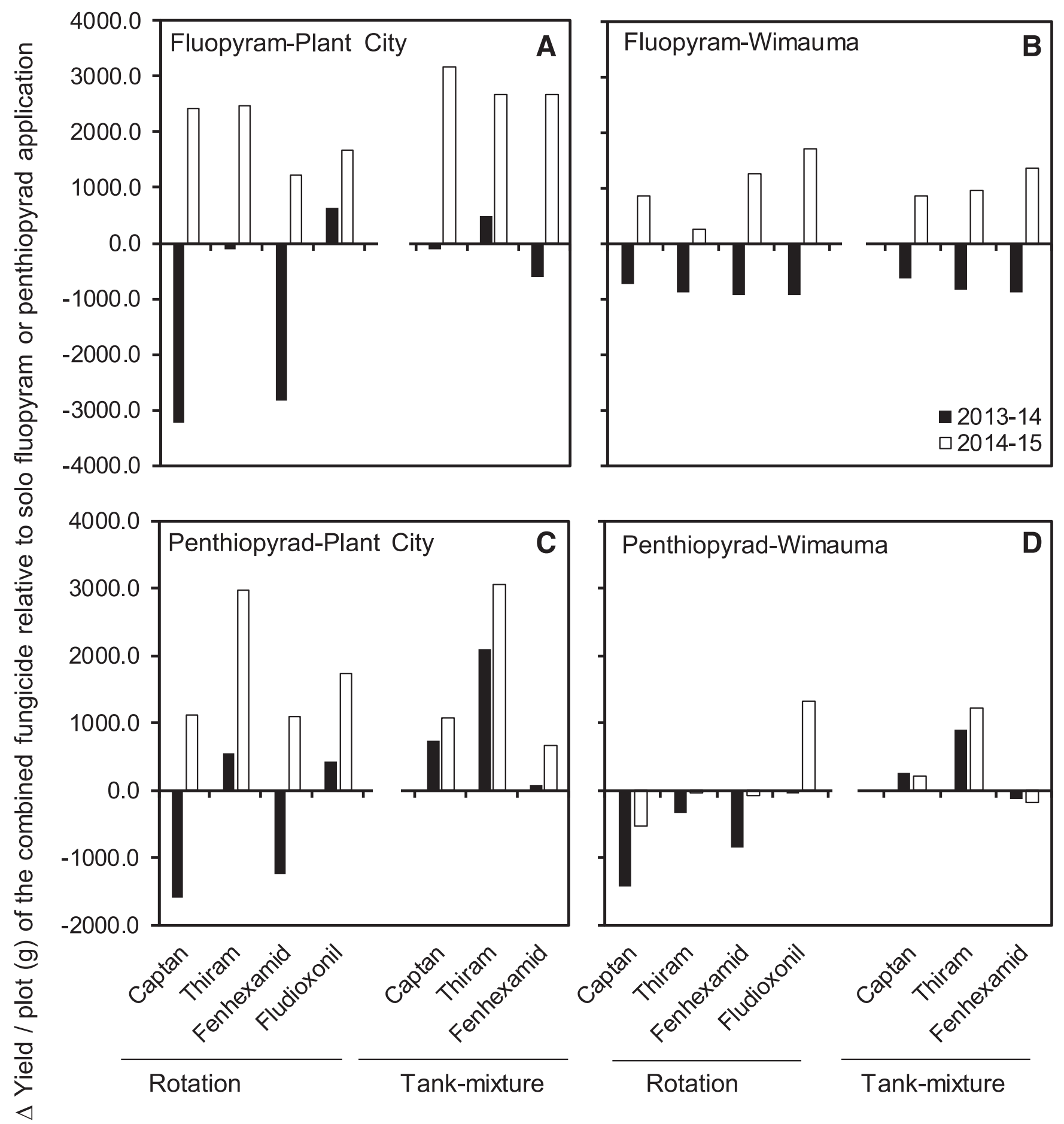

Fig. 2. Relative efficacy of rotation and tank-mixture programs with fluopyram and penthiopyrad in Plant City (A and $\mathbf{C})$ and Wimauma (B and D) on yield expressed as the difference in yield ( $\Delta$ yield) between the tank-mixture and rotation program, minus the yield from the solo application of fluopyram or penthiopyrad. 
mixture reduced BFR incidence more than $60 \%$. Under high disease pressure conditions in 2015, a similar trend was observed, although the efficacy of the treatments was lower than in 2014. The multirotational program, consisting of six fungicides applied throughout the season, reduced BFR by 38 to $78 \%$ depending on the year and location (Table 4).

Application of captan as a solo product reduced BFR incidence by only 14 to $35 \%$, and differences were not significant from the control (Table 4). Although captan rotated or tank mixed with fluopyram reduced disease incidence significantly, neither rotation nor tank mixture with penthiopyrad was effective in reducing BFR incidence across locations and seasons (Table 4). The single-site fenhexamid rotated or tank mixed with fluopyram reduced BFR incidence by 52 to
$89 \%$ but failed, in most cases, when applied with penthiopyrad, as no significant differences from the control were observed (Table 4).

Additive, synergistic, and antagonistic interactions of captan and thiram with the SDHIs. The multisites captan and thiram had additive interactions with the SDHI fluopyram whether rotated or tank mixed in both seasons at the commercial field and in 2015 at the experimental field (Table 5). Additive interactions were also observed between the SDHI penthiopyrad and the multisite thiram, because the expected values were not significantly different from the actual BFR \% control values (Table 5). In contrast, an antagonistic interaction was observed between penthiopyrad and captan, because the actual BFR \% control values were significantly lower than the expected values in both seasons at the commercial field and in 2015 at the

Table 4. Efficacy of fluopyram and penthiopyrad applied alone and in rotational or tank-mixture programs on reduction of annual Botrytis fruit rot (BFR) incidence ${ }^{\mathrm{z}}$

\begin{tabular}{|c|c|c|c|c|c|c|c|}
\hline \multirow[b]{3}{*}{ Treatment no. } & \multirow[b]{3}{*}{ SDHI } & \multirow[b]{3}{*}{ Strategy } & \multirow[b]{3}{*}{ Partner } & \multicolumn{4}{|c|}{ Reduction of BFR incidence (\%) } \\
\hline & & & & \multicolumn{2}{|c|}{$\begin{array}{l}\text { Commercial field } \\
\text { (Plant City) }\end{array}$} & \multicolumn{2}{|c|}{$\begin{array}{c}\text { Experimental field } \\
\text { (Wimauma) }\end{array}$} \\
\hline & & & & $2013-14$ & $2014-15$ & 2013-14 & 2014-15 \\
\hline 2 & & Single & Captan & $14.5^{*}$ & $23.0 *$ & 35.1 & $28.0 *$ \\
\hline 3 & & & Thiram & 53.8 & 46.2 & $\ldots$ & 50.9 \\
\hline 4 & & & Fluopyram & 84.0 & 50.8 & 67.5 & 57.0 \\
\hline 5 & & & Penthiopyrad & $31.8^{*}$ & 37.2 & 58.0 & 40.0 \\
\hline 6 & Fluopyram & Rotated & Captan & 82.8 & 57.1 & 67.0 & 62.4 \\
\hline 7 & & & Thiram & 84.0 & 56.1 & $\ldots$ & 74.5 \\
\hline 8 & & & Fenhexamid & 88.8 & 51.8 & 59.8 & 70.9 \\
\hline 9 & & & Fludioxonil & 84.0 & 59.8 & 74.2 & 82.4 \\
\hline 10 & & Tank mixed & Captan & 87.6 & 60.5 & $\ldots$ & 64.8 \\
\hline 11 & & & Thiram & 85.8 & 62.8 & $\ldots$ & 75.8 \\
\hline 12 & & & Fenhexamid & 84.0 & 60.5 & $\ldots$ & 77.6 \\
\hline 13 & Penthiopyrad & Rotated & Captan & $18.0^{*}$ & $32.0^{*}$ & 57.7 & 41.2 \\
\hline 14 & & & Thiram & 48.5 & 41.9 & & 66.1 \\
\hline 15 & & & Fenhexamid & $22.0^{*}$ & $13.0^{*}$ & 63.9 & $22.0^{*}$ \\
\hline 16 & & & Fludioxonil & 74.0 & 54.2 & 68.0 & 69.7 \\
\hline 17 & & Tank mixed & Captan & $12.0 *$ & $29.0 *$ & $\ldots$ & 40.6 \\
\hline 18 & & & Thiram & 68.0 & 55.5 & $\ldots$ & 72.1 \\
\hline 19 & & & Fenhexamid & $34.0^{*}$ & $23.0^{*}$ & $\ldots$ & $33.0 *$ \\
\hline 20 & Multirotation & & Multiple & 77.5 & 38.2 & 66.0 & 70.9 \\
\hline
\end{tabular}

${ }^{\mathrm{z}}$ Data are expressed as percent reduction in BFR incidence compared with the nontreated control from four replicates. Values followed by an asterisk are not significantly different following an ANOVA and mean separation using Fisher LSD test at $P \leq 0.05$. SDHI $=$ succinate dehydrogenase inhibitor.

Table 5. Synergistic, additive, and antagonistic interaction observed between the multisites captan and thiram and the succinate dehydrogenase inhibitors (SDHIs) fluopyram and penthiopyrad in rotation and tank-mixture treatments

\begin{tabular}{|c|c|c|c|c|c|c|c|}
\hline \multirow[b]{3}{*}{ Strategy } & \multirow[b]{3}{*}{ Treatment $^{\mathrm{x}}$} & \multicolumn{6}{|c|}{ Actual and expected BFR incidence (\%) } \\
\hline & & \multicolumn{2}{|c|}{ Plant City 2013-14 } & \multicolumn{2}{|c|}{ Plant City 2014-15 } & \multicolumn{2}{|c|}{ Wimauma 2014-15 } \\
\hline & & Act $^{\mathbf{y}}$ & $\operatorname{Exp}^{\mathbf{z}}$ & Act & $\operatorname{Exp}$ & Act & $\operatorname{Exp}$ \\
\hline \multirow[t]{4}{*}{ Solo product } & Captan solo & $14.5 \mathrm{e}$ & $\ldots$ & $23.0 \mathrm{c}$ & $\ldots$ & $28.0 \mathrm{c}$ & $\ldots$ \\
\hline & Thiram solo & $53.8 \mathrm{~b}$ & $\ldots$ & $46.2 \mathrm{~b}$ & $\ldots$ & $50.9 \mathrm{ab}$ & $\ldots$ \\
\hline & Fluopyram solo & $84.0 \mathrm{a}$ & $\ldots$ & $50.8 \mathrm{~b}$ & $\ldots$ & $57.0 \mathrm{a}$ & $\ldots$ \\
\hline & Penthiopyrad solo & $31.8 \mathrm{~d}$ & $\ldots$ & $37.2 \mathrm{c}$ & $\ldots$ & $40.0 \mathrm{~b}$ & $\ldots$ \\
\hline \multirow[t]{4}{*}{ Fluopyram } & R_Captan & $82.8 \mathrm{a}$ & $86.3 \mathrm{~ns}$ & $57.1 \mathrm{a}$ & $62.1 \mathrm{~ns}$ & $62.4 \mathrm{a}$ & $69.0 \mathrm{~ns}$ \\
\hline & TM_Captan & $87.6 \mathrm{a}$ & $86.3 \mathrm{~ns}$ & $60.5 \mathrm{a}$ & $62.1 \mathrm{~ns}$ & $64.8 \mathrm{a}$ & $69.0 \mathrm{~ns}$ \\
\hline & R_Thiram & $84.0 \mathrm{a}$ & $92.6 \mathrm{~ns}$ & $56.1 \mathrm{a}$ & $73.5 \mathrm{~ns}$ & $74.5 \mathrm{a}$ & $78.9 \mathrm{~ns}$ \\
\hline & TM_Thiram & $85.8 \mathrm{a}$ & $92.6 \mathrm{~ns}$ & $62.8 \mathrm{a}$ & $73.5 \mathrm{~ns}$ & $75.8 \mathrm{a}$ & $78.9 \mathrm{~ns}$ \\
\hline \multirow[t]{4}{*}{ Penthiopyrad } & R_Captan & $18.0 \mathrm{e}$ & $41.7^{*}$ & $32.0 \mathrm{c}$ & $51.6^{*}$ & $41.2 \mathrm{~b}$ & $56.8 *$ \\
\hline & TM_Captan & $12.0 \mathrm{e}$ & $41.7^{*}$ & $29.0 \mathrm{c}$ & $51.6^{*}$ & $40.6 \mathrm{~b}$ & $56.8 *$ \\
\hline & R_Thiram & $48.5 \mathrm{c}$ & $58.5 \mathrm{~ns}$ & $41.9 \mathrm{~b}$ & $56.2 \mathrm{~ns}$ & $66.1 \mathrm{a}$ & $70.5 \mathrm{~ns}$ \\
\hline & TM_Thiram & $68.0 \mathrm{~b}$ & $58.5 \mathrm{~ns}$ & $55.5 \mathrm{a}$ & $56.2 \mathrm{~ns}$ & $72.1 \mathrm{a}$ & $70.5 \mathrm{~ns}$ \\
\hline
\end{tabular}

${ }^{\mathrm{x}} \mathrm{R}$ and TM indicate the SDHI fungicide is rotated or tank mixed, respectively, with captan or thiram.

${ }^{y}$ Act $=$ average actual Botrytis fruit rot (BFR) $\%$ control observed in the plots. Values within the actual $\%$ control columns followed by the same letters are not significantly different following an ANOVA and mean separation using Fisher LSD test at $P \leq 0.05$.

${ }^{\mathrm{z}}$ Exp $=$ expected BFR \% control calculated using the formula $E=X+[Y(100-X)] / 100$, where $X$ is the actual control value in plots treated with one partner of the rotation or tank mixture and $Y$ is the actual control value in plots treated with the other partner of the rotation or tank mixture. ns $=$ not significant, and asterisks indicate significant differences. 
experimental field. Data from the experimental field in Wimauma during 2013-14 are not shown because not all treatments were conducted.

\section{Discussion}

This study is part of ongoing efforts to develop more sustainable management approaches for BFR in strawberry. Our results point out the need to select appropriate rotation or tank-mix partners to enhance the efficacy and extend the life span of newly registered single-site fungicides. Although our study focused on the SDHIs, the approach and findings could be applied to ensure a selection of the most effective programs of other new registered single-site fungicides, especially those known to have a "high risk" for resistance development.

There was a significant treatment effect on yield except in the 2013-14 season in Wimauma, where disease pressure is usually lower than in the main production area around Plant City. Overall, tank mixtures increased yield more than rotations of the two SDHIs with different partners. Thiram had a greater effect than captan, especially when partnered with penthiopyrad (Fontelis). Although discrepancies have been reported in previous studies, most of them reported a greater effect of thiram than captan on yield and reduction of Botrytis infections. Thus, thiram was found to impact yield equally to some single-site fungicides such as fluazinam (Menzel et al. 2016; Washington et al. 1992), iprodione (Blacharski et al. 2001), thiophanate-methyl and benomyl (La Mondia 2001; Washington et al. 1992), and fenhexamid and penthiopyrad (Cordova et al. 2017; Menzel et al. 2016; Walter et al. 2005). For example, thiram resulted in a $1,900 \mathrm{~kg} / \mathrm{ha}$ increase compared with captan in Florida (Legard et al. 2001), whereas Wedge et al. (2007) reported that the effect of captan on yield was not different from the nontreated control in strawberry fields in Louisiana and Mississippi and that combination with fenhexamid did not increase yield compared with fenhexamid alone. The rotation of fludioxonil + cyprodinil (Switch) with either SDHI had a greater effect on yield than when they were mixed with fenhexamid (Elevate). This is consistent with previous reports (Cordova et al. 2017; Wedge et al. 2007) and certainly owing to the high potency of fludioxonil and the absence of resistance to it in Florida (Amiri et al. 2013). However, 30 to $40 \%$ of B. cinerea isolates in Florida were resistant to fenhexamid in 2013 and 2014 (Amiri et al. 2013). Although growers may follow spray programs different from the ones tested herein, our results suggest a positive impact on yield of partnering fungicides over solo applications, especially under high disease pressure. One possible way to benefit from the impact of mixtures or rotations that may not be feasible throughout the season is to target the most critical infection timing, such as first bloom in November and also the peak bloom period in February (in Florida), when the Strawberry Advisory System forecasts favorable conditions for BFR infections.

The different treatments (i.e., rotations and tank mixtures) affected BFR incidence differentially. Solo applications of fluopyram were significantly more effective than penthiopyrad in both years and locations. A greater efficacy of fluopyram compared with penthiopyrad and other SDHIs has been reported previously against $B$. cinerea in strawberry (Amiri et al. 2014; Cordova et al. 2017; FernándezOrtuño et al. 2014) and other pathogens (Avenot et al. 2014; Villani et al. 2016). The benzamide moiety, unique to fluopyram, allows an extended binding to the $\mathrm{Q}$ pocket of the succinate dehydrogenase complex (Scalliet et al. 2012), resulting in its higher potency compared with others SDHIs. Similarly, solo thiram applications significantly reduced BFR incidence compared with captan. Our results corroborate previous studies reporting a better efficacy of thiram compared with captan (Blacharski et al. 2001; Legard et al. 2001; Menzel et al. 2016; Xiao et al. 2001). This greater potency could be related to a longer persistence of thiram on the plant and fruit surface, which extends the protection; a higher intrinsic activity of thiram, as evidenced by lower $\mathrm{EC}_{50}$ values compared with folpet, a sister molecule of captan (Leroux 2004); or the presence of resistance or reduced sensitivity to captan in strawberry fields, as reported recently in Florida blueberry fields (Amiri et al. 2018).

Findings from this study suggest that not all fungicides can be effectively used as a partner with the two new SDHIs and that future decisions may be made case-by-case depending on the fungicide and the pathosystem. The "low risk" single-site fungicide fludioxonil and the multisite fungicide thiram were good partners for both SDHIs, because their rotation and tank mixture (thiram only) reduced BFR incidence to the lowest level compared with most other treatment combinations. The absence of $B$. cinerea isolates resistant to fludioxonil (Amiri et al. 2013) and the low resistance frequency to both SDHIs in Florida strawberry fields (Amiri et al. 2014) likely account for the greater efficacy in all treatments that included fludioxonil. The latter is known to target all growth stages of the fungus (i.e., inhibiting spore germination, germ tube elongation, and mycelial growth) as well as its ability to induce germ tube distortions and cell bursting (Rosslenbroich and Stuebler 2000). Thiram and captan had additive interactions with fluopyram, as did thiram with penthiopyrad. Several previous studies have shown a similar or slightly better efficacy of thiram over captan against Botrytis infections (Blacharski et al. 2001; Legard et al. 2001; Wedge et al. 2007; Xiao et al. 2001). However, it is unclear why captan failed to provide adequate efficacy even under low disease pressure in 2014. The success of fungicides in a mixture or rotation is defined by their ability to decrease the aggressiveness and fitness of the pathogen and perhaps increase fungicide uptake of one or both partners that will result in a higher concentration within the fungal cell and lead to its death (Cohen and Gisi 1993; De Waard 1996). Whether thiram enhances penthiopyrad uptake, whereas captan and fenhexamid decrease its uptake, remains unknown and requires further investigation.

The different behavior of fenhexamid, captan, and thiram with the two SDHIs can possibly be explained by different scenarios with a potential major impact on disease management: First, mixing or rotating two effective fungicides such as fluopyram with thiram, which showed a greater efficacy in this study, and fludioxonil, also effective against BFR (Cordova et al. 2017), will enhance the efficacy or at least will not result in a decreased control. These strategies could be ideal under high disease pressure to control the major part of the population and reduce its exposure to the same active ingredient. Second, mixing or rotating a highly effective fungicide such as fluopyram with a moderately effective single-site fungicide such as fenhexamid or a less effective product such as captan will not reduce disease control because the efficacy is likely conferred by the most effective active ingredient in the treatment, which is fluopyram in this case. This may suggest that rotation of such partners may reduce risks of fungicide resistance development, and tank mixtures may not provide high control levels. Third, mixing or rotating two fungicides with a moderate efficacy such as thiram and penthiopyrad can result in a significantly increased efficacy if the two fungicides are compatible. Indeed, in our study solo thiram applications provided about $50 \%$ BFR reduction, significantly greater than four applications of penthiopyrad alone. However, their rotation or tank mixture reduced BFR incidence significantly. Fourth, mixing or rotating fungicides with low or moderate efficacies and that might not be compatible can result in antagonist effects. This scenario is better exemplified by the combination of captan, which was not significantly different from the nontreated control, or fenhexamid, known for its moderate efficacy (Amiri et al. 2014; Cordova et al. 2017) with penthiopyrad, which showed only 22 to $40 \%$ BFR reduction in our study.

This study emphasizes the need to develop appropriate spray programs upon registration of new fungicides to enhance efficacy and perhaps extend their lifespan. We provide evidence for the need to select appropriate rotation and tank-mix partners to use with highrisk fungicides such as the SDHIs to control polycyclic fungi such as $B$. cinerea. We also show that mixtures may be more effective than rotations of the same fungicides for disease management. Tank mixture of fluopyram with thiram or rotation with fludioxonil is recommended under higher disease pressure during the peak bloom period, whereas tank mixing penthiopyrad with thiram should provide acceptable efficacy levels under moderate disease pressure during or outside the peak production period. Whether the same impact on selection for resistance populations in this particular fungus is true remains unknown and will be addressed in a follow-up study. 
Additional studies testing different combinations and different rates of fungicides that were not compatible in this study will help understand the role of other parameters on the efficacy of fungicides in mixtures or rotations.

\section{Acknowledgments}

We thank R. Martin for technical assistance and participating growers for their cooperation.

\section{Literature Cited}

Amiri, A., Heath, S. M., and Peres, N. A. 2013. Phenotypic characterization of multifungicide resistance in Botrytis cinerea isolates from strawberry fields in Florida. Plant Dis. 97:393-401.

Amiri, A., Heath, S. M., and Peres, N. A. 2014. Resistance to fluopyram, fluxapyroxad, and penthiopyrad in Botrytis cinerea from strawberry. Plant Dis. 98:532-539.

Amiri, A., and Peres, N. A. 2014. Diversity in the erg27 gene of Botrytis cinerea field isolates from strawberry defines different levels of resistance to the hydroxyanilide fenhexamid. Plant Dis. 98:1131-1137.

Amiri, A., Peres, N. A., and Whidden, A. 2012. Perspective on resistance of Botrytis cinerea from strawberry to multiple fungicides in Florida. Special alert. Berry Vegetable Times, IFAS Extension. University of Florida, Gainesville. https://gcrec.ifas.ufl.edu/media/gcrecifasufledu/docs/pdf/berrynewsletter/BVT0312.pdf

Amiri, A., Zuniga, A. I., and Peres, N. A. 2018. Potential impact of populations drift on Botrytis occurrence and resistance to multi- and single-site fungicides in Florida southern highbush blueberry fields. Plant Dis. 102:2142.

Avenot, H. F., van den Biggelaar, H., Morgan, D. P., Moral, J., Joosten, M., and Michailides, T. J. 2014. Sensitivities of baseline isolates and boscalidresistant mutants of Alternaria alternata from pistachio to fluopyram, penthiopyrad, and fluxapyroxad. Plant Dis. 98:197-205.

Blacharski, R. W., Bartz, J. A., Xiao, C. L., and Legard, D. E. 2001. Control of postharvest Botrytis fruit rot with preharvest fungicide applications in annual strawberry. Plant Dis. 85:597-602.

Chandler, C. K., Santos, B. M., Peres, N. A., and Jouquand, J. 2009. 'Florida Radiance' strawberry. HortScience 44:1769-1770.

Cohen, Y., and Gisi, U. 1993. Uptake, translocation and degradation of ${ }^{14} \mathrm{C}$ cymoxanil in tomato plants. Crop Prot. 12:284-292.

Cordova, L. G., Amiri, A., and Peres, N. A. 2017. Effectiveness of fungicide treatments following the Strawberry Advisory System for control of Botrytis fruit rot in Florida. Crop Prot. 100:163-167.

Couch, H. B., and Smith, B. D. 1991. Synergistic and antagonistic interactions of fungicides against Pythium aphanidermatum on perennial ryegrass. Crop Prot. 10:386-390.

De Waard, M. A. 1996. Synergism and antagonism in fungicides mixtures containing sterol demethylation inhibitors. Phytopathology 86:1272-1275.

Fernández-Ortuño, D., Grabke, A., Bryson, P. K., Amiri, A., Peres, N. A., and Schnabel, G. 2014. Fungicide resistance profiles in Botrytis cinerea from strawberry fields in seven southern U.S. states. Plant Dis. 98:825-833.

Gowing, D. P. 1960. Comments on test of herbicide mixtures. Weeds 8:379-391.

Köller, W., and Wilcox, W. F. 2001. Evidence for the predisposition of fungicideresistant isolates of Venturia inaequalis to a preferential selection for resistance to other fungicides. Phytopathology 91:776-781.

La Mondia, J. A. 2001. Management of Euonymus Anthranose and fungicide resistance in Colletotrichum gloeosporioides by alternating of mixing fungicides. J. Environ. Hort. 19:51-55.

Legard, D. E., MacKenzie, S. J., Mertely, J. C., Chandler, C. K., and Peres, N. A. 2005. Development of a reduced use fungicide program to control of Botrytis fruit rot on annual strawberry. Plant Dis. 89:1353-1358.
Legard, D. E., Xiao, C. L., Mertely, J. C., and Chandler, C. K. 2001. Management of Botrytis fruit rot in annual winter strawberry using captan, thiram, and iprodione. Plant Dis. 85:31-39.

Leroux, P. 2004. Chemical control of Botrytis and its resistance to chemical fungicides. Pages 195-222 in: Botrytis: Biology, Pathology and Control. Y. Elads, ed. Springer, Dordrecht, the Netherlands.

Luo, C.-X., and Schnabel, G. 2008. Adaptation to fungicides in Monilinia fructicola isolates with different fungicide resistance phenotypes. Phytopathology 98:230-238.

MacKenzie, S. J., and Peres, N. A. 2012. Use of leaf wetness and temperature to time fungicide applications to control Botrytis fruit rot of strawberry in Florida. Plant Dis. 96:529-536.

Menzel, C. M., Gomez, A., and Smith, L. A. 2016. Control of grey mold and stemend rot in strawberry plants growing in a subtropical environment. Austral. Plant Pathol. 45:489-498.

Mertely, J. C., Chandler, C. K., Xiao, C. L., and Legard, D. E. 2000. Comparison of sanitation and fungicides for management of Botrytis fruit rot of strawberry. Plant Dis. 84:1197-1202.

Oliveira, M. S., Amiri, A., Zuniga, A. I., and Peres, N. A. 2017. Sources of primary inoculum of Botrytis cinerea and their impact on fungicide resistance development in commercial strawberry fields. Plant Dis. 101:1761-1768.

Pavan, W., Fraise, C. W., and Peres, N. A. 2011. Development of a web-based disease forecasting system for strawberries. Comput. Electron. Agric. 75:169-175.

Rosslenbroich, H. J., and Stuebler, D. 2000. Botrytis cinerea-history of chemical control and novel fungicides for its management. Crop Prot. 19:557-561.

Scalliet, G., Bowler, J., Luksch, T., Kirchhofer-Allan, L., Steinhauer, D., Ward, K. Niklaus, M., Verras, A., Csukai, M., Daina, A., and Fonne-Pfister, R. 2012. Mutagenesis and functional studies with succinate dehydrogenase inhibitors in the wheat pathogen Mycosphaerella graminicola. PLoS One 7:e35429.

Schoustra, S. E., Slakhorst, M., Debets, A. J. M., and Hoekstra, R. F. 2005 Comparing artificial and natural selection in rate of adaptation to genetic stress in Aspergillus nidulans. J. Evol. Biol. 18:771-778.

Staub, T. 1991. Fungicide resistance: Practical experience with anti-resistance strategies and the role of integrated use. Annu. Rev. Phytopathol. 29: 421-442.

Villani, S. M., Ayer, K., and Cox, K. D. 2016. Molecular characterization of the $s d h B$ gene and baseline sensitivity to penthiopyrad, fluopyram, and benzovindiflupyr in Venturia inaequalis. Plant Dis. 100:1709-1716.

Walter, M., Harris-Virgin, P., Morgan, C., Stanley, J., Boyd-Wilson, K. S. H., Langford, G. I., and Moore, M. S. 2005. Fungicides for control of flower and berry infections of Botrytis cinerea in boysenberry. Crop Prot. 24: 625-631.

Washington, W. S., Shanmuganathan, N., and Forbes, C. 1992. Fungicide control of strawberry fruit rots, and the field occurrence of resistance of Botrytis cinerea to iprodione, benomyl and dichlorofluanid. Crop Prot. 11:355-360.

Wedge, D. E., Smith, B. J., Quesbedeaux, J. P., and Constantin, R. J. 2007. Fungicide management strategies for control of strawberry fruit rot disease in Louisiana and Mississippi. Crop Prot. 26:1449-1458.

Whitaker, V. M., Boyd, N. S., Peres, N. A., Noling, J. W., and Renkeam, J. 2017 Strawberry production. Pages 293-312 in: Vegetable and Small Fruit Production Handbook of Florida. G. E. Vallad, H. Smith, P. J. Dittmar, and J. H. Freeman, eds. IFAS Extension, University of Florida, Gainesville.

Whitaker, V. M., Chandler, C. K., Bielinski, M. S., Peres, N. A., do Nascimento Nunes, M. C., Plotto, A., and Sims, C. A. 2012. Winterstar ${ }^{\text {TM }}$ ('FL 05-107') strawberry. HortScience 47:296-298.

Xiao, C. L., Chandler, C. K., Price, J. F., Duval, J. R., Mertely, J. C., and Legard, D. E. 2001. Comparison of epidemics of Botrytis fruit rot and powdery mildew of strawberry in large plastic tunnel and field production systems. Plant Dis. 85: 901-909.

This article was modified on 16 Aug 2019. 


\section{ERRATUM / Volume 103, Number 4, 2019 / PDIS-07-18-1276-RE}

In the article, "The Importance of Selecting Appropriate Rotation and Tank-Mix Partners for Novel SDHIs to Enhance Botrytis Fruit Rot Control in Strawberry" by Achour Amiri, Adrian I. Zuniga, Leandro G. Cordova, and Natalia A. Peres, there was an error in an equation. The equation was written as $E=X-[Y(100-X)] / 100$, but the correct equation should read $E=X+[Y(100-X)] / 100$. The equation appears on page 731 in the Data Collection and Analyses section, as well as on page 734 in footnote $\mathrm{z}$ of Table 5.

(C) 2019 The American Phytopathological Society 